\title{
RELAÇÕES DE TRABALHO NO MERCOSUL
}

Lourival José de Oliveira

SUMÁRIO: 1. Introdução. 2. A flexibilização das relaçôes de trabalho. 3. A circulação de trabalhadores na União Européia. 4. As relações laborais quanto à normas trabalhistas nacionais. 5 . As investidas sindicais no Mercosul. 6. Conclusão. 7. Bibliografia.

SUMMARY: 1. Introduction. 2. The flexibilization of the work's relations. 3. The worker's circulation in the European Union. 4. The work's relations and the national labor's norms. 5. The union attacks in the Mercosul. 6. Conclusion. 7. Bibliography.

SUMARIO: 1. Introducción. 2. El flexibilización de las relaciones del trabajo. 3. La circulación del trabajador en la Unión Europea. 4. Las relaciones del trabajo y las normas nacionales del trabajo. 5. Los ataques de los sindicatos en el Mercosul. 6. Conclusión. 7. Bibliografia.

RESUMO: A circulação de pessoas no âmbito das comunidades, especialmente no que diz respeito ao Mercosul é de fundamental importância, a fim de que se dinamize as relações sociais e económicas, contribuindo conseqüentemente para a participação da sociedade civil na discussão dos planos econômicos, do conceito e forma de participação dos Estados nacionais. 
ABSTRACT: People's circulation in economic blocks, especially in Mercosur is very important because it is supposed to dinamize the social and economic relation. It contributes to the participation of the civil society in the discussion of economic plans in the concept and form of the states participation

RESUMEN: La circulación de las personas en las comunidades, especialmente en el MERCOSUR es muy importante porque se supone la dinamización de la relación social y económica. Contribuye para la participación de la sociedad civil en la discusión de planos económicos en el concepto y forma de participación de los Estados nacionales.

PALAVRAS-CHAVES: Mercosul. Relaçôes internacionais de trabalho. Circulaçâo de trabalhadores.

KEY-WORDS: Mercosur. International work relation. Circulation of workers.

PALABRAS-LLAVES: MERCOSUR. Relaciones internacionales del trabajo. Circulación de los trabajadores.

\section{Introdução}

Em que medida a integração do Brasil no Mercosul permitiu uma democratização no campo das relações de trabalho? Qual é o grau de participação dos sujeitos laborais no Mercosul? Não é possível estudar a integração regional de trabalhadores na América Latina sem que seja feito referência à chamada "nova ordem mundial". E no caso, essa nova ordem apresenta-se quase que inquestionável, expressada pela terminologia globalização.

A mão-de-obra tornou-se globalizada. Praticamente já não existem duras restriçōes em se utilizar do trabalho além fronteira. A prioridade é a redução de custos sociais. Logo, quanto mais barata a mão-de-obra, melhor para a produção. Atualmente, no México, mais de 1 milhão de trabalhadores percebem em torno de 3 dólares por dia de trabalho, sem encargos sociais, trabalhando para empresas americanas. A UNCTAD ( Conferência das Nações Unidas para o Comércio e Desenvolvimento) já avaliou, desde 1996, que aproximadamente 40.000 empresas mantém fábricas em mais de 3 países. A multinacionais já dominam $2 / 3$ de todo o comércio mundial. 
Dentro desse contexto de mundialização, os Estados-nações vem delegando o seu poder decisório. Hoje, quem dita as normas são as grandes agências internacionais de investimentos. A maior delas é a agência Moody's Investors Service, que chega a classificar os Estados dentro de um "ranking" financeiro, partindo do grau "Aaa", de acordo, principalmente com a existência de uma moeda forte, estável, que se tornou sinônimo de poder. A hegemonia financeira é a cotação do câmbio.

Sendo assim, para a União Européia, a formação do bloco, com a criação de uma moeda comum, a sincronia de suas políticas financeiras e tributárias é uma forma de os países europeus se oporem a essse mercado mundial competitivo. Enquanto para os mais pobres, como é o caso do Mercosul, é a possibilidade de exportar produtos primários e oferecer mão-de-obra barata, facilitando os grandes grupos em suas operaçôes transnacionais.

O que realmente vem acontecendo é a redefinição do papel do Estado na sociedade, com o aumento do protecionismo nos países centrais. A abertura dos Estados que mantém uma mão-de-obra barata e a preservação do protecionismo para aqueles que já detém urma hegemonia econômica.

Dessa maneira é importante deixar de início firmado que é o interesse do lucro privado que orienta a integração no Mercosul e não outros objetivos, como por exemplo o desenvolvimento com justiça social e a integração entre várias nações, de modo a formar uma verdadeira comunidade.

Fica dessa forma, em princípio, justificada a ênfase que é dada ao Mercosul, desde 1991, orientando-se para os projetos de liberalização do mercado de trabalho, defendendo-se a flexibilização dos contratos de trabalho, a fim de que se adequem à necessidade competitiva da empresa. Da mesma maneira, promover a desestruturação do movimento sindical e dos demais movimentos sociais reinvidicadores de direitos (Argentina).

\section{A flexibilização das relações de trabalho}

Teve-se assim o incremento de uma economia regionalizada para uma economia globalizada, essencialmente no plano econômico, sempre em busca de maior produção e produtividade com menor custo. A esse fenômeno chamou-se reestruturação produtiva. A reestruturação produtiva significa a redução do número de emprego, com a contribuição do avanço tecnológico, para a redução dos custos e o aumento da competitividade, mudando a forma como o trabalho é realizado. 
E as questões sociais? Não é possível deixar de constar quase que uma ausência de questões sociais no Mercosul, em confronto com aquilo que foi colocado no Tratado de Assunção de 1991. O desenvolvimento econômico no Mercosul foi colocado para atingir a justiça social. Segundo a Carta de Assunção, a integração melhoraria a capacidade, competitividade das indústrias, permitindo uma retomada do crescimento econômico, em busca da conquista da justiça social.

Desta feita, foi criado o chamado sub-grupo $\mathrm{n}^{\mathrm{a}} 11$, que atualmente corresponde ao grupo 10. No entanto, ainda que frente as propostas sociais apresentadas para o Mercosul, quais foram os seus interlocutores. Ou seja, até o momento, quais são os participantes no Mercosul? São os governos dos paises integrantes, através dos Ministérios das Relações Exteriores, Ministérios da Economia e Bancos Centrais dos países pactuantes. Quer dizer, a população ainda não foi chamada a participar do Mercosul.

Outra pergunta que é possivel de ser feita: o que tem sido discutido no Mercosul quanto ao direito do trabalho? Reunindo-se e fazendo uma sintese dos encontros que ocorreram ao longo dos últimos 10 anos, temse como conclusão que o único tema das discussões foi a facilitação na contratação e no despedimento, do empregado. No entanto, segundo dados fornecidos pela própria ONU (Organização das Nações Unidas), entre 1960 a 1980 houve um aumento de $15 \%$ no número de latinoamericanos que viviam abaixo da linha da pobreza. Entre 1980 a 1988 , houve um aumento de $27 \%$. No mesmo período, a estimativa percentual de sub-emprego era de $44 \%$ da população ativa. Somente na Argentina, a taxa de desemprego já ultrapassou $18 \%$ neste segundo semestre ${ }^{1}$.

Ao reboque desse processo de flexibilização aponta-se um desafio para os grandes conglomerados econômicos que é a busca da homogeneização das relações de trabalho. De outro lado, propõe-se a harmonização das legislaçôes nacionais, que é um pouco diferente da homogeneização, uma vez que o que se pretende com a harmonização é a eliminação das diferenças.

Ocotre que, com a fraca participação das Centrais Sindicais, tem-se defendido a ratificação de Convenções internacionais da Organização Internacional do Trabalho (OIT), que estabelecem um mínimo de direitos sociais e trabalhistas que devem ser respeitados pelos países integrantes do Mercosul.

Contudo, nem uma primeira proposta, nem outra conseguiram ser efetivamente discutidas, planejadas e propostas até o presente momento.

1 Fonte: "O Estado de São Paulo". 


\section{A circulação de trabalhadores na União Européia.}

O princípio da livre circulação de pessoas no ordenamento comunitário europeu compreende somente o trabalho assalariado, encontrando-se regulado no artigo $3^{\mathrm{a}}$ do Tratado da Comunidade Econômica Européia, onde se estabeleceu a livre circulação de pessoas entre os Estados-membros. Contudo, em princípio, houve uma certa dificuldade para aprovar referida idéia, principalmente devido à proteção que se observava na proteção do mercado nacional de trabalho contra o trabalhador estrangeiro. Contudo, começou a ser superada referida dificuldade com o Tratado de Maastricht, de 1992, que trouxe uma equiparação legal do comunitário com o nacional para que deixasse de existir diferenças com relação ao tratamento dispensados e que também cessassem as dicriminações. Segundo Augusto Jaeger Júnior: ... é por força destes mandamentos que o ordenamento comunitário impõe aos Estadosmembros que o trabalhador tenha em sua relação laboral um tratamento igual ao dado ao seu próprio nacional, não somente nas questóes relacionadas a livre circulação, mas em todas as demais questões comunitánias. E não unicamente a ele, mas também ao seu cônjuge, descendentes menores de vinte um anos e ascendentes que tenham se deslocado com ele ou que estejam em seu encargo, desde que nacionais de um dos Estados-membros. ${ }^{2}$ Desta maneira, a União Européia contempla hoje em seu ordenamento jurídico comunitário, como pressuposto para a livre circulação de pessoas, o direito de residência, ao livre deslocamento e o direito de fazer-se acompanhar pela família. $O$ direito de resistência implica no dever dos Estados-partes suprimirem totalmente as restrições existentes quanto ao deslocamento, permanência e residência dos cidadãos dos demais Estados-membros. Contudo, o Estado comunitário receptor poderá exigir, como condição prévia à concessão dessa permissão, que o cidadão imigrante tenha condições financeiras suficientes, superiores ao que o Estado-membro concede na assistência social aos seus nacionais, em um seguro de doença, para não produzir encargos ao Estado receptor.

Sendo assim, o Tratado da União Européia incorporou o direito de livre circulação, o direito de resistência, estabelecendo para as pessoas duas qualidades, quais sejam, a de nacional de um Estado-membro e a de nacional da comunidade. Um outro grande avanço foi o direito ao

Jaeger Júnior, Augusta. Mercosul e a Livre Circulaçăo de Pessoas, p. 66 e 67. 
sufrágio ativo e passivo, que trata do direito do cidadão eleger e de ser eleito nas eleições municipais do Estado-membro de residência, em condições iguais aos que têm os nacionais desse Estado.

\section{As relaçóes laborais quanto às normas trabalhistas nacionais.}

No caso da Argentina, tudo indica que a proposta atual em termos de legislação trabalhista é a desregulamentação. No Paraguai, nas relações individuais de trabalho, mantém a intervenção básica do Estado. No que tange às relações coletivas, seguir as recomendações da Organização Internacional do Trabalho. No Uruguai, talvez por ser marcado por um menor número de textos de lei sobre matéria trabalhista, as Convenções Internacionais (OIT) se constituem em fontes formais de direito.

Diante desse quadro algumas sugestôes apareceram. Dentre várias, vale citar a que foi defendida por Sussekind, que sugeriu uma "Carta Social" contendo apenas os princípios fundamentais do Direito do Trabalho e da Seguridade Social, que deveriam ser observados pelos Estadosmembros do Mercosul, em harmonia com suas condições sócioeconômica. Dentro desse plano, ganha asas a defesa da harmonização das legislações dos países que fazem parte do Mercosul, se comparado com a proposta de uniformização.

São muitas as questões laborais que devem ser acordadas e legisladas no que tange ao Mercosul. Contudo, os temas principais devem ser os encargos trabalhistas, a migração de trabalhadores e a harmonização das normas para a circulação de trabalhadores, a implantação de um sistema comunitário de informações, a seguridade social e a fiscalização do trabalho. Por enquanto, visto que nenhum dos temas propostos foram verdadeiramente discutidos, os estrangeiros dos países-membros que venham a trabalhar no Brasil ficam sujeitos à Lei $6.815 / 80$, que disciplina a situação jurídica do estrangeiro no Brasil, independentemente de que país faça parte, e os brasileiros que trabalham fora do Brasil ficam sujeitos às normas dos países cm que estejam trabalhando, de acordo com a Súmula 207 do TST, donde se tem que a lei que rege as relações trabalhistas é a do país onde o serviço é prestado, e não do local onde houve a contratação.

'Esses dircitos sociais estão contemplados no artigo $8^{\underline{a}}$ do Tratado da Comunidade Economica Européia (TCEE) e săo indispensáveis à concretzaçăo da livre circulaçăo de pessoas. No Mercosul, referido assunto ainda näo foi alvo de discussâo. 
O processo integracionista não pode ser contemplado apenas sobre o fator econômico. O Tratado de Assunção apresentou uma estrutura institucional provisória, onde havia um Conselho do Mercado Comum (CMC) e um Grupo de Mercado Comum ( GMC). No período de 1991 a 1994 muitos setores criaram comissões "ad hoc" e subgrupos de traba1ho, sobre vários temas, que posteriormente acabaram verdadeiramente sendo desativados. No caso de questões ligadas ao direito do trabalho surgiu o SG11 que depois passou para SG 10. É de fundamental importância que no Mercosul seja buscado objetivos e a promoção da circulação de pessoas, a fim de que ocorra conseqüentemente a participação civil no processo de integração. Contudo, conforme vem sendo afirmado no decorrer desse trabalho, a sociedade civil é excluída e não está representada nas decisóes do bloco econômico e em suas conseqüências.

Embora na Comunidade Européia tenha a integração de trabalhadores tenha alcançado um grau respeitado, para Augusto Jaeger Júnior, a sociedade civil também deixou de participar das discussões sobre o tema, existindo ainda obstáculos que impedem ou dificultam a circulação de trabalhadores naquela comunidade.

\section{As investidas sindicais no Mercosul}

Foi criada no início da década de 90 a Coordenadoria das Centrais Sindicais do Cone Sul. Participaram para a sua criação, dentre outras entidades, a COB (Central Obreira Boliviana), o MIT ( Movimento Intersindical de Trabalhadores Paraguaios, o CNT (Comando Nacional dos Trabalhadores, a Central Democrática de Trabajadores Chilenos, A CGT ( Central Geral dos Trabalhadores) Argentina, a CUT ( Central Única dos Trabalhadores ) do Brasil.

Antes do Tratado de Assunção (1991), já se desenvolvia alguns contatos entre essas referidas entidades, em torno da democratização da América Latina e discussão da divida externa. Com o Mercosul, o tema da discussão sofreu alterações. Desta feita, no mesmo ano de 1991, no $4^{a}$ Congresso da CUT, no Brasil, lançou-se a discussão em torno do chamado "sindicalismo sem fronteiras", que teve como resultado uma Carta de Direitos Fundamentais, que foi quase que uma cópia fiel das Convenções Internacionais da Organização Internacional do Trabalho. Talvez, face ao vínculo das entidades sindicais ao Estado, falta de pessoal qualificado, 
falta de habilidade das próprias entidades sindicais, que ainda encontramse habituadas a enfrentarem somente os problemas imediatos, o movimento acabou esvaziando-se.

A abertura econômica sobrepôs à integração regional e com os cortes dos custos o SGT-11 ( Subgrupo "relações Trabalhistas, Emprego e Seguridade Social) acabou somente com o papel meramente consultivo, onde os sindicatos não mais participaram das reuniões.

Outra questão de grande importância na Carta de Direitos Fundamentais foi a indicação da necessidade da criação de um Tribunal Regional. Contudo, a criação de um Tribunal sustenta a tese da supranacionalidade, e por enquanto, tudo indica que o Mercosul caminha para a intergovernabilidade, o que é diferente.

A partir de janeiro de 1995 ficou evidente os caminhos do Mercosul e a inviabilidade da chamada Carta de Direitos Fundamentais, ficando os representantes sindicais dos diversos países signatários do acordo à margem de qualquer outra discussão de peso político.

Quanto à Seguridade Social, foi encaminhada para a reunião de Ouro Preto (1994) uma proposta de contagem recíproca do tempo de trabalho, que nem em votação foi colocada.

O que desponta é na verdade um Mercosul até 1994, que tinha objetivos ambiciosos, que visavam a constituição de um mercado comum e outro Mercosul a contar do início de 1995, com objetivos como a consolidação de uma zona de livre comércio, com a implantação de uma união aduaneira entre os países pactuantes. Deixaram de existir as comissóes permanentes, passando para comissões que integravam o referido subgrupo a se reunirem de acordo com as contingências e de forma aleatória.

\section{Conclusão}

A migração de mão-de-obra no Mercosul ainda encontra-se isenta de uma regulamentação, embora seja uma questão primordial para que verdadeiramente se estruture uma verdadeira comunidade, a fim de que crie-se o cidadão do Mercosul. Contudo, tudo indica que esse ideário está longe de acontecer. A crise que no momento abate-se sobre a Argentina, principalmente, contribui para que ocorra uma desaceleração no aprofundamento do processo integracionista, muito embora deva ser deixado claro que principalmente nos últimos 05 anos de Mercosul, a 
busca da cidadania e do respeito aos nacionais enquanto participantes de uma comunidade não foram os objetivos primordiais. Ao mesmo tempo tem-se a não participação da sociedade organizada, de forma a demonstrar que a circulação de trabalhadores, quando discutida, não buscou objetivos integracionistas e sim de redução de custos e a própria desregulamentação do direito do trabalho, de forma a atender outros objetivos, principalmente no que tange ao barateamento da mão-de-obra.

\section{BIBLIOGRAFIA}

ALMEIDA, Paulo Roberto de. Mercosul: Fundamentos e Perspectivas. São Paulo: LTr, 1998.

BAPTISTA, Luiz Olavo; MERCADANTE, Araminta de Azevedo; CASELlA, Paulo Borba (Orgs.). Mercosul: Das Negociações à Implantação, $2^{\circ}$ ed. São Paulo: LTr, 1998, p. 17-173, 224-267.

BASSO, Maristela (Org.). Mercosul: Seus Efeitos Jurídicos, Económicos e Políticos nos Estados-membros. $2^{\circ}$ ed. Porto Alegre: Livraria do Advogado, 1997, p.117-153 157-186, 443-459.

BRANCO, Luizella Giardino B. Sistema de Solução de Controvérsia no Mercosul: Perspectivas para a criação de um modelo institucional permanente. São Paulo: LTr, 1997.

CORDEIRO, Wolney de Macedo. A Regulamentação das Relaçóes de Trabalho Individuais e Coletivas no Ambito do Mercosul. São Paulo: LTr, 2000.

DOBROWOLSKI, Silvio (Org.). A Constituição no Mundo Globalizado. Florianópolis: Diploma Legal, 2000, p. 283-299.

FARIA, Werter R (Org.). Estudos sobre Integração. Porto Alegre: Livraria do Advogado, 2000, p. 35-54, 73-108, 177-192, 209-223.

FREITAS JR., Antônio Rodrigues de. Globalização, Mercosul e Crise do Estado-Nação: Perspectivas para o Direito numa Sociedade em Mudança. São Paulo: LTr, 1997, p. 41-61.

GARCIA IR., Armando Alvares. O Direito do Trabalho no Mercosul. São Paulo: LTr,1997.

JAEGER JR., Augusto. Mercosul e a Livre Circulação de Pessoas. São Paulo: LTr, 2000.

MARTINS, Eliane M. O.; GADIG, Washington L. F. REVISTA DO 
DIREITO TRABALHISTA. Brasilia: Ed. Consulex, ano 5, $\mathrm{n}^{\mathrm{a}}$ 09, set. 1999 , p. 24.

MARTINS, Eliane M. O.; LUPATELLI JR., Alfredo. REVISTA JURÍDICA CONSULEX. Brasília: Ed. Consulex, ano III, $\mathrm{n}^{\mathrm{a}}$ 33, set. 1999, p. 43-45.

VIGEVANI, Tullo. Mercosul: Impactos para Trabalhadores e Sindicatos. São Paulo: LTr, 1998. 